\title{
TRADISI BERSIH DESA DI LERENG GUNUNG BROMO
}

\author{
T.M Rita Istari \\ (Balai Arkeologi Yogyakarta)
}

\begin{abstract}
Bersih Desa tradition in Pusungmalang, Puspo, Pasuruan is one among various ritual worships. The purpose is to ask for a savety over the danyang in the village. The existence of this tradition cannot be separated from its environment because they are interconnected to each other. The tradition occurs in Javanese people where animism elements are still influenced their mindset, ideology as well as their daety routinity. The Javanese people believed in mystic world or supranatural where every objects regarded as having its own spirit.

Pusungmalang which consists of five villages, still keeps the harmonious relationship between humans and their nature. They believed if a violation occurs then disaster would come.
\end{abstract}

Key words: Tradisi - Bersih Desa - Danyang - Punden

\section{PENDAHULUAN}

\section{Lokasi}

Desa Pusungmalang termasuk wilayah Kecamatan Puspo, Kabupaten Pasuruan, terletak di lereng Gunung Penanjakan salah satu anak Gunung Bromo, dengan ketinggian 1340 meter dpl (dari permukaan laut) dan koordinat LS $07^{\circ} 51^{\prime} 11,4^{\prime \prime}$ dan BT 112 $55^{\prime} 34,4^{\prime \prime}$. Dari kota Pasuruan untuk menuju ke desa tersebut melalui beberapa desa, antara lain Desa Gondangwetan, Desa Pasrepan, dan Desa Puspo. Kemudian jalan mulai naik menelusuri bukit-bukit yang berkelok-kelok dan terjal kurang lebih selama dua jam perjalanan dengan kendaraan roda empat, barulah sampai ke desa Pusungmalang. Desa Pusungmalang terdiri atas lima dusun yaitu: Mangu, Wonogriyo, Kenongo, Jagungsromo, dan Pusungmalang. Di lokasi ini selama empat tahun Balai Arkeologi Yogyakarta sudah melakukan empat tahap penelitian (satu tahap, setiap satu tahun), dan berhasil mengidentifikasikan, tinggalan arkeologi berbentuk punden berundak dari masa Hindu yang dinamakan Candi Sanggar oleh penduduk setempat, yang terletak di Dusun Wonogriyo (Istari, 2009:2).

\section{Pengertian Tradisi}

Kata "tradisi" berasal dari bahasa Latin traditio yang berarti: riwayat, adat, ajaran turun temurun, dan warisan nenek moyang (Poerwadarminto, 
1976:413). Sayogya dalam Ensiklopedi Nasional Indonesia jilid 16, mengatakan "tradisi" adalah kebiasaan yang diwariskan dari satu generasi ke generasi berikutnya secara turun temurun. Kebiasaan yang diwariskan mencakup berbagai nilai budaya, yang meliputi adat-istiadat, sistem kemasyarakatan, sistem pengetahuan, bahasa, kesenian, dan sistem kepercayaan. Seorang individu dalam lingkungan suatu masyarakat akan mempelajari proses budaya yang terdapat dalam masyarakat tersebut. la akan bertindak sesuai dengan nilai-nilai budaya yang dipelajarinya. Nilai budaya yang menjadi pedoman tingkah laku bagi masyarakat adalah warisan yang telah mengalami proses penyerahan dari satu generasi ke generasi berikutnya. Proses ini menyebabkan nilai-nilai budaya tertentu menjadi tradisi yang biasanya terus dipertahankan oleh masyarakat tersebut (Sayogya, 1991:414).

Tradisi erat kaitannya dengan kepercayaan atau agama dan juga dengan kebudayaan. Pengertian agama di sini menyangkut pula bermacam-macam kepercayaan, misalnya kepercayaan kepada arwah nenek moyang (animisme), kepercayaan kepada kekuatan gaib (dinamisme), kepercayaan kepada benda-benda pusaka (fetisisme), dan kepercayaan kepada kekuatan magis. Selaras dengan gerak langkah di bidang pembangunan menyebabkan pula terjadi pergeseran dan perubahan di bidang budayanya. Di sinilah perlu peranan pemerintah untuk mengembangkan nilai-nilai budaya bangsa Indonesia dengan melestarikan dan membina nilai-nilai luhur hasil kebudayaannya. Hasil kebudayaan itu di antaranya adalah upacara tradisional yang masih dilakukan oleh sebagian masyarakat Indoesia sampai sekarang (Soetama, 1988:1). Dalam Garisgaris Besar Haluan Negara Tap MPR No. II/MPR/1988 halaman 379, tujuan pelestarian budaya tradisional bangsa Indonesia disebutkan sebagai berikut:

Mengembangkan nilai budaya Indonesia guna memperkuat kepribadian bangsa, mempertebal rasa harga diri dan kebanggaan nasional. Pengembangan kebudayaan nasional, diarahkan kepada nilai-nilai yang mencerminkan kepribadian bangsa dan meningkatkan nilai-nilai luhur serta mencegah nilai sosial budaya feodal kedaerahan yang sempit. Membina tradisi dan peninggalan sejarah yang mempunyai nilai perjuangan bangsa dan kebanggaan serta kemanfaatan nasional

Masyarakat Indonesia memiliki bermacam-macam bentuk tradisi terutama yang berkaitan dengan kemampuan tentang local genius. Pengertian local genius pada hakekatnya juga berarti kemampuan bangsa Indonesia dalam menyerap kebudayaan asing dan menyesuaikan dengan kebudayaan lokal. Karena itu pada masa sekarang ini kemampuan local genius tersebut sangat penting diterapkan untuk menangkal segala pengaruh kebudayaan asing yang negatif. Untuk masa lampau, Wales 
(1948:49) membedakan pengaruh kebudayaan Hindu yang menyebar di Asia Tenggara dibedakan menjadi dua.

a. Akulturasi keras: yang menyebar di Campa, Kamboja, Thailand, dan Birma, yang menerima sepenuhnya sehingga kebudayaan lokalnya lama kelamaan ditinggalkan dan lenyap begitu saja.

b. Akulturasi lunak: yang menyebar di Indonesia, pada waktu kebudayaan Hindu masuk ke Indonesia, diterima sepenuhnya dan kemudian disesuaikan dengan kebudayaan lokal, sehingga tidak lenyap sama sekali.

Dapat dikatakan bahwa tradisi dengan berbagai aspek simboliknya mencerminkan norma-norma serta nilai-nilai budaya suatu bangsa dengan latar belakang budaya yang berbeda. Disadari bahwa norma dan nilai budaya merupakan unsur penting yang ikut menentukan identitas kebudayaan yang tersebar di seluruh pelosok tanah air, meskipun telah mendapat pengaruh dari budaya asing. Pengaruh itu dapat bersifat positif maupun negatif. Bersifat positif, apabila berbagai bentuk tradisi yang telah disepakati bersama oleh sekelompok masyarakat masih memiliki daya tarik untuk masa sekarang dalam usaha untuk membentuk kepribadian bangsa. Namun tradisi itu berubah apabila sudah tidak cocok lagi dengan kemajuan jaman. Dengan demikian, tradisi itu selalu berkembang dan mengalami perubahan oleh pengaruh budaya asing. Tradisi dikatakan bersifat negatif apabila bersifat menghambat kemajuan dan pembangunan dalam masyarakat yang bersangkutan (Moertjipto, 1997/8:108).

Subalidinata (1982:1-2) mengatakan bahwa tradisi adalah suatu masalah kebiasaan sekelompok masyarakat, sekelompok keluarga, maupun perorangan. Kebiasaan sekelompok masyarakat pada hakekatnya disusun oleh kebiasaan dan lingkungan keluarga. Kebiasaan yang telah teratur tata-caranya disebut adat-istiadat. Kebiasaan ini sering mengikat dan memaksa sesorang atau sekelompok masyarakat untuk mematuhi dan melakukannya. Jika tradisi diabaikan dapat mendatangkan bahaya atau bencana. Yang sering dipermasalahkan, apakah tradisi itu masih berguna bagi masyarakat modem sekarang ini?. Mungkin jawabannya adalah: berguna, dengan alasan karena sebagian orang menganggap tradisi adalah warisan nenek moyang yang sedikit banyak tentu masih mengandung unsur-unsur kebudayaan yang bermanfaat.

\section{PROSESI UPACARA BERSIH DESA DI PUSUNGMALANG}

Masyarakat Desa Pusungmalang yang mempunyai tradisi upacara bersih desa telah melakukan tradisi ini secara turun-temurun, setiap dua tahun sekali. Pada tahun 2009 ini, upacara tersebut diselenggarakan pada tanggal 17 Juli bertepatan dengan hari Jumat Legi menurut perhitungan penanggalan Jawa. Memang upacara ini harus dilakukan pada hari Jumat Legi. Upacara dilakukan oleh ke lima dusun di wilayah Desa 
Pusungmalang, tetapi dipusatkan di Dusun Wonogriyo karena puncak acara diadakan di Candi Sanggar yang dianggap sebagai tempat tinggal danyang utama desa tersebut. Dana untuk penyelenggaraan acara, ditanggung bersama-sama oleh seluruh masyarakat Desa Pusungmalang. Setiap keluarga menyumbang sesuai dengan jumlah yang sudah ditentukan, dan akan dicatat oleh panitia. Selain itu, dana juga diambil dari kas desa, dan sumbangan para donatur.

Pelaksanaan upacara bersih desa dapat dibagi menjadi tiga acara yaitu: Acara pembukaan, arakan ancak-ancak, dan acara kesenian. Ke tiga acara tersebut dilaksanakan pada hari yang yang sama.

Rangkaian pelaksanaan dalam upacara, adalah sebagai berikut.

\section{Acara Pembukaan:}

Upacara dimulai sejak pagi hari diawali dengan berkumpulnya seluruh masyarakat Desa Pusungmalang di balai desa yang terletak di Dusun Wonogriyo. Setelah pembacaan doa-doa, dilanjutkan dengan arakarakan mengunjungi delapan punden yang ada di desa Pusungmalang tersebut. Di wilayah Kecamatan Puspo setiap desa mempunyai minimal satu punden, sedangkan Pusungmalang mempunyai delapan punden yang tersebar di lima dusun wilayahnya. Punden, menurut kepercayaan masyarakat adalah tempat tinggal atau tempat bersemayamnya roh-roh leluhur yang disebut danyang. Oleh sebab itu pada waktu-waktu tertentu mereka harus melakukan upacara untuk menghormati para danyang tersebut, agar mereka selalu menjaga seluruh masyarakat desanya, dan menghindarkan penduduk desa dari mala-petaka dan gangguan roh-roh jahat.

Delapan punden yang didatangi dalam upacara tersebut adalah:

1. Setran atau kuburan desa.

2. Perempatan desa yang menghubungkan ke lima dusun.

3. Jambu, yang berada di bawah pohon besar (tidak diketahui alasan digunakannya nama Jambu, yang pasti saat ini di lokasi itu, tidak ditemukan pohon jambu!).

4. Kali Kenongo yaitu sumber mata air yang terletak di utara desa.

5. Candi Sanggar, tempat acara puncak diadakan, terutama halaman candi ini sebab danyang utama diyakini bersemayam di sini.

6. Halaman bangunan Sekolah Dasar Pusungmalang.

7. Kali Sumberrejo yaitu sumber mata air yang terletak di sebelah selatan desa.

8. Pertigaan desa, di persimpangan jalan yang salah satunya menuju ke arah Tengger.

Pelaku upacara terutama terdiri atas kepala desa, sesepuh desa, dukun, perantara, pesinden/tayub, dan rombongan penabuh gamelan (musik tradisional) yang masing-masing mempunyai tugas sendiri. 
Kepala Desa, harus diikutsertakan karena jabatan administratifnya.

$>$ Sesepuh desa, dilibatkan karena mereka dianggap berjasa terhadap desa, misalnya mantan pejabat desa.

$>$ Dukun, bertugas untuk memimpin doa-doa di setiap punden sebelum upacara dimulai, dengan mempersembahkan sesaji yang berupa tujuh macam unsur (bunga-bungaan, hasil bumi dan sebagainya) sambil membakar kemenyan dan sabut kelapa. Mereka melantunkan mantramantra dalam bahasa Jawa kuna, sampai upacara berakhir di punden tersebut.

$>$ Perantara, adalah seorang sesepuh desa yang mempunyai kelebihan dapat berkomunikasi (sebagai mediator) dengan para danyang di punden-punden tersebut. Dengan mata batinnya, perantara akan menyampaikan kepada para pesinden, tembang apa yang harus dinyanyikan. Jadi perantara ini memegang peranan penting untuk memulai dan mengakhiri upacara di setiap punden. Tentu saja waktu menyanyi di setiap punden tidak selalu sama, tergantung dari para danyang yang bersemayam di sana.

> Sinden/Tayub, yang dilibatkan biasanya berjumlah tiga orang wanita. Mereka bertugas untuk menyanyikan tembang-tembang yang diminta oleh danyang melalui perantara. Mereka menyanyi (nembang) bersamasama dengan kepala desa dan perantara tadi.

$>$ Rombongan penabuh gamelan tentu saja bertugas membawa seperangkat gamelan untuk mengiringi tembang-tembang yang dinyanyikan para sinden.

Sebagaimana telah disebutkan di atas, bahwa upacara Bersih desa ini dilakukan dengan mendatangi delapan punden yang ada di Desa Pusungmalang. Desa ini secara geografis terletak diperbukitan, dan Candi Sanggar berada di atas bukit tertinggi, sedangkan pemukiman penduduk Desa Pusungmalang berada di bawah bukit tersebut.

Upacara dimulai dari punden pertama yaitu Setran/kuburan desa, dilanjutkan berturut-turut pada punden-punden berikutnya searah jarum jam (dari timur ke barat). Namun tepat pada tengah hari mereka harus berada di atas bukit tempat Candi Sanggar berada, sebagai tempat puncak upacara diadakan. Candi Sanggar diyakini sebagai tempat bersemayamnya danyang utama Desa Pusungmalang yang bernama Kyai Wonosodo (Istari,2009:1). Sedang tujuh punden lainnya adalah tempat persemayaman danyangdanyang yang memiliki tingkat lebih rendah daripada danyang utama tadi. Oleh sebab itu, upacara di halaman Candi Sanggar ini berlangsung lebih lama dan tembang yang dinyanyikan lebih banyak. Tembang harus dimulai dengan gending eling-eling sebagai lagu pembuka (Jawa = kulonuwun) kepada danyang yang tinggal di punden tersebut. Kemudian diteruskan dengan tembang-tembang lain sesuai permintaan danyang melalui perantara tadi. Selanjutnya tembang akan diakhiri dengan gending undurundur yang berarti mohon pamit kepada danyang, dan menandakan upacara di punden itu sudah selesai yang akan dilanjutkan ke punden- 
punden berikutnya. Sebagai penutup upacara, kepala desa secara simbolis memberi uang sebagai upah kepada para sinden, kemudian para peserta dipersilahkan minum-minum. Sebenarnya menurut tradisi, minuman yang disediakan berupa tuak yang akan membuat mereka mabuk. Namun sekarang minuman yang memabukkan itu dilarang oleh pemerintah, sehingga diganti dengan air putih bahkan minuman masa kini yaitu Sprite!!!

\section{Arakan Ancak-ancak:}

Setelah upacara ke delapan punden selesai pada sore hari, acara dilanjutkan dengan kedatangan ancak-ancak (semacam Gunungan Sekaten di Kraton Yogyakarta dan Surakarta) yang dibuat oleh penduduk lima dusun wilayah Desa Pusungmalang itu. Setiap dusun menyumbang ancak-ancak sesuai dengan kemampuannya. Pada upacara tahun 2009 ini terkumpul 18 ancak-ancak. Ancak-ancak tersebut dikumpulkan di halaman balai desa. Ancak-ancak dibuat dari anyaman bambu, di atasnya ditancapkan hasil bumi mentah maupun yang sudah diolah menjadi makanan, hewan (ayam dan itik), dan dihiasi dengan kertas-kertas dan balon-balon aneka warna agar menarik, hal ini tergantung dari kreatifitas pembuatnya. Sesudah ancak-ancak terkumpul, dukun melaksanakan tugasnya lagi dengan membaca doa-doa dan mantra-mantra. Sebagai puncak acara masyarakat memperebutkan ancak-ancak tersebut, dan apa yang berhasil didapat akan mereka simpan di rumah masing-masing. Masyarakat masih percaya akan kekuatan sakti (tuah) yang terdapat dalam ancak-ancak. Apabila seseorang berhasil mendapatkan jumlah banyak, dianggap sebagai pertanda akan memperoleh keuntungan yang besar dalam kehidupannya tahun ini.

\section{Acara Kesenian:}

Malam harinya diteruskan dengan acara kesenian yang berlangsung hingga tengah malam. Sesuai dengan perkembangan jaman, kini pada malam kesenian mereka mengundang satu grup kesenian dari luar kota yang terdiri atas para pemain musik atau penabuh gamelan yang akan mengiringi para sinden menyanyi dan para tayub menari. Seperti yang telah disebutkan di atas, bahwa penyelenggaraan upacara ini didanai oleh seluruh masyarakat desa dan para donatur. Sebagai imbalan, para penyumbang dipersilahkan duduk di tempat terhormat dengan para undangan lainnya dan menikmati hidangan yang telah disuguhkan. Selain itu, mereka juga diperbolehkan meminta tembang yang dinyanyikan sinden, maupun menari dengan para tayub.

\section{TRADISI BERSIH DESA DAN PARIWISATA:}

Agar suatu upacara mempunyai makna dan dianggap berhasil dalam pencapaian tujuannya, maka upacara itu harus dilandasi dengan emosi keagamaan. Menurut Koentjaraningrat (1977:234) yang dimaksud dengan emosi keagamaan adalah, 
Suatu getaran jiwa yang pada suatu ketika pemah menghinggapi seseorang manusia dalam jangka waktu tertentu di dalam hidupnya, walaupun getaran itu mungkin hanya berlangsung beberapa detik saja, untuk kemudian menghilang kembali.

Emosi keagamaan yang terdapat dalam upacara dapat membangkitkan perasaan religius dalam pelaksanaan upacara. Jika tidak dilandasi dengan emosi keagamaan yang tinggi, maka akan terjadi ketidakseimbangan hubungan antara manusia dengan alam, karena sebagian dari tujuan upacara adalah untuk menyelaraskan hubungan antara manusia dengan alam (Widodo, 1991:72). Demikian juga halnya dengan upacara bersih desa.

Secara harafiah bersih desa berarti membersihkan desa agar terhindar dari roh-roh jahat, dan merupakan bentuk upacara kesuburan. Biasanya upacara ini dilakukan setelah masa panen, karena pada masa itu penduduk terutama para petani sudah selesai panen padi dan semuanya mempunyai hasil bumi untuk selamatan. Bersih desa merupakan bentuk ritual kesuburan yang paling besar, karena penyelenggaraan upacara ini melibatkan penduduk seluruh desa yang terdiri atas beberapa dusun. Setiap keluarga diwajibkan menyumbang dan mengikuti jalannya upacara ke punden, biasanya berupa pohon besar, sendang, sungai maupun ujung batas desa. Kelengkapan sesaji merupakan unsur penting di dalam upacara yang meliputi cara penyajian, sesajen, urutan atau jalannya upacara yang semua itu menjadi ritual karena dilakukan berulang-ulang, rutin dalam setiap tahun atau waktu yang telah ditentukan.

Upacara ini dilakukan oleh masyarakat desa dan ditujukan kepada danyang yang tinggal menetap pada suatu tempat yang disebut punden. Danyang merupakan roh seorang tokoh masyarakat setempat yang sudah meninggal dan yang dianggap pada masa hidupnya telah berjasa kepada desa bersangkutan. Setiap desa biasanya mempunyai beberapa danyang dan satu danyang utama. Para danyang itu dianggap pula dapat mengabulkan segala permohonan orang atau masyarakat yang memohon kepadanya, dan sebagai imbalannya mereka mendapat persembahan dalam bentuk upacara-upacara tradisi. Danyang dikaitkan juga dengan Kumara, yang oleh Clifford Geertz (1989:32-33) dijelaskan sebagai berikut.

Daerah yang berada pada kekuasaan danyang desa disebut Kumara. Kumara atau Këmara berarti suara yang tiba-tiba muncul dari ketiadaan, sebagai contoh misalnya, seorang dukun termasyur meninggal, suatu hari sesudah dia meninggal tiba-tiba ada seseorang yang mendengar suaranya tanpa ketahuan dari mana sumbernya. Dengan demikian kumara meliputi seluruhn ruang angkasa desa, di mana orang biasa mendengar suara manusia yang berbicara dari dalam tanah. Sebagai tambahan, di ke empat ujung desa atau batas wilayah desa dianggap dihuni oleh para roh 
pelindung, yang merupakan anak-anak dari danyang utama, yang bertempat tinggal di pusat desa.

Dalam pelaksanaan upacara bersih desa bisa terjadi danyang melalui perantara atau mediator meminta syarat khusus, selain sesajen yang berupa hasil bumi dan bunga-bungaan. Oleh sebab itu dalam upacara kelengkapan sesaji menjadi unsur yang amat penting. Apabila kurang lengkap dapat mengakibatkan danyang marah dan akan mendatangkan malapetaka bagi penduduk desa yang bersangkutan.

Sebenarnya upacara bersih desa ini dapat dikaitkan dengan kepariwisataan, karena tradisi ini cukup menarik. Selain itu, para wisatawan juga dapat berkunjung ke Candi Sanggar meskipun kini keadaannya hanya berupa reruntuhan saja. Yang lebih menarik lagi adalah perjalanan menuju ke situs, melewati jalan setapak, naik ke perbukitan dengan pemandangan yang indah di bawahnya. Dari desa ini perjalanan dapat pula dilanjutkan menuju ke kawah Tengger Gunung Bromo. Apabila paket wisata ini dapat terlaksana tentu akan membawa dampak peningkatan kesejahteraan masyarakat. Pada dasarnya suatu budaya diciptakan masyarakat untuk mendukung kehidupannya. Hasil budaya memang dapat dikembangkan sebagai obyek kepariwisataan, seperti pendapat Nyoman $S$ Pandit (1981:140, Widodo, 1991:99) tentang hubungan antara budaya dan pariwisata sebagai berikut.

...harus memelihara (termasuk pengawasan dan bimbingan) nilai kekayaan budaya yang dalam hal ini harus dimaksudkan dengan benda-benda yang merupakan monumen sejarah dan suasana warisan budaya masa lampau, masa kini dan yang akan datang, di mana proyek konsenasi baginya harus ditujukan kepada soal-soal ekonomi, sosial dan peradaban bangsa.

Salah satu usaha peningkatan kesejahteraan dapat dilakukan melalui pembangunan di bidang pariwisata, antara lain dengan memanfaatkan obyek-obyek wisata beserta menyediakan sarana akomodasinya.

Hingga kini penyelenggaraan upacara di Pusungmalang masih dikelola oleh masyarakat desa yang bersangkutan dengan menyusun panitia secara sukarela. Dana penyelenggaraan ditanggung oleh seluruh masyarakat, selain juga didapat dari pungutan pajak yang berasal dari para penjual makanan, pedagang, dan parkir. Pedagang-pedagang tersebut berdagang sejak pagi hari hingga tengah malam sampai selesainya seluruh prosesi upacara . Mereka berdatangan dari luar desa bahkan juga dari kotakota lain sekitar Pasuruan. 


\section{PENUTUP}

Upacara bersih desa merupakan acara simbolis mempersembahkan sesaji dalam bentuk hasil bumi kepada arwah para leluhur yang disebut danyang. Tujuannya adalah agar para danyang bersedia menjaga seluruh masyarakat di wilayah desa tersebut, supaya mereka terhindar dari segala mala-petaka dan gangguan roh-roh jahat.

Sesaji dilakukan sebagai perwujudan rasa syukur kepada Sang Pencipta atas segala ciptaanNya, dengan harapan akan kembali kepada masyarakat berupa kemakmuran dan kesejahteraan hidupnya.

Upacara bersih desa merupakan salah satu warisan budaya lokal yang perlu dilestarikan, dan masyarakat desa di lereng Gunung Bromo ini telah membuktikannya. Pelestarian tradisi tersebut memang perlu dilakukan, sehingga masyarakat akan tetap dapat menangkap semangat kebersamaan dan gotong-royong, serta rasa peduli dengan budaya sendiri tanpa harus mengorbankan keyakinan yang mereka anut. Pada masa sekarang tradisi semacam ini dianggap sebagai budaya yang kolot dan kuna. Generasi penerus sudah mulai enggan mengikuti tradisi tersebut. Namun, bagaimana pun juga tradisi ini memang perlu dipertahankan, karena dapat menjadi identitas budaya setempat. Jika budaya suatu daerah itu hilang, maka ciri khas daerah tersebut juga akan ikut hilang. Apalagi, tradisi ini juga mengandung nilai-nilai budaya yang luhur, seperti kebersamaan, gotong royong, rasa syukur kepada yang mahakuasa, dan sekaligus melestarikan lingkungan alam.
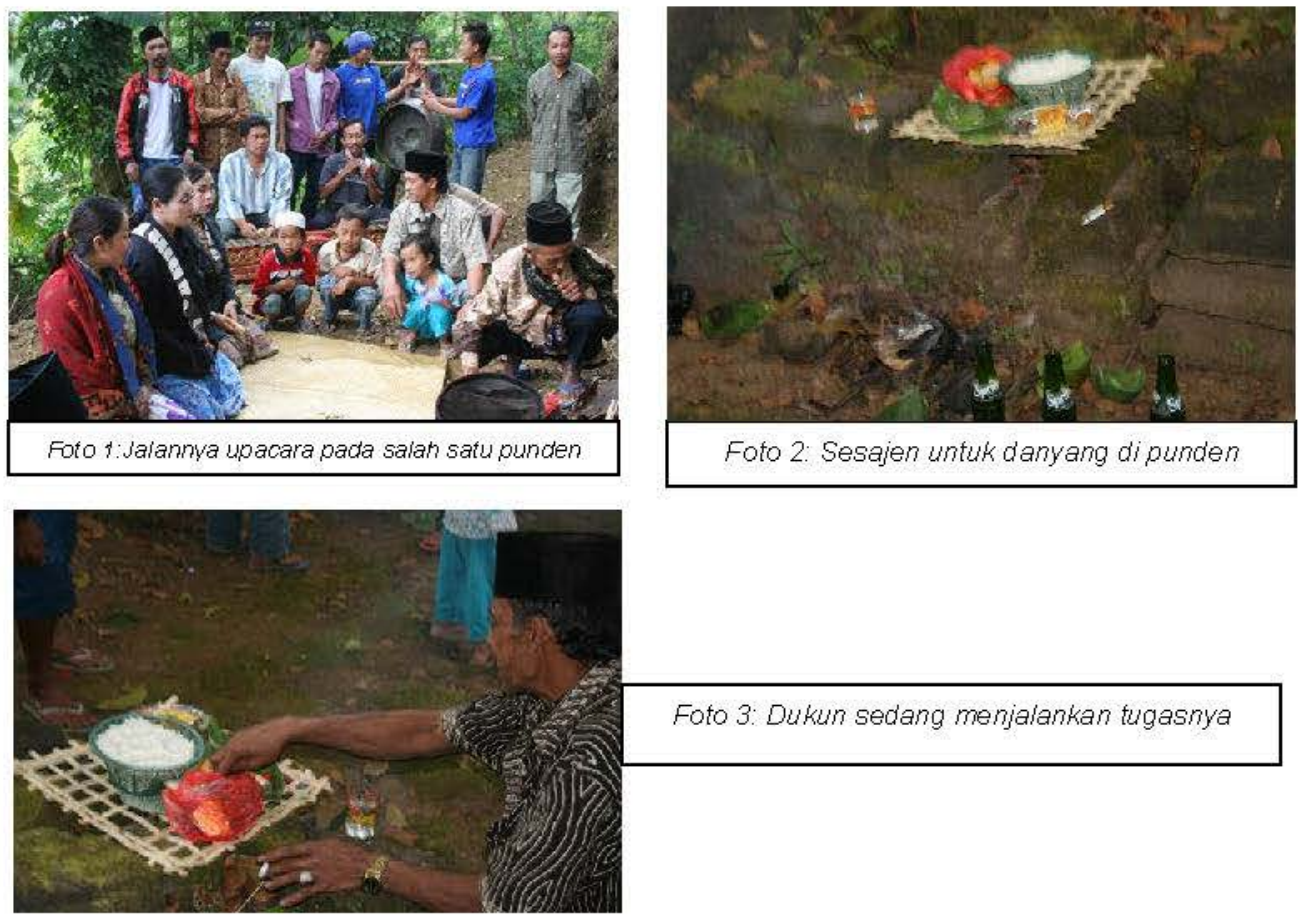

Foto 3: Dukun sedang menjalankan tugasnya 

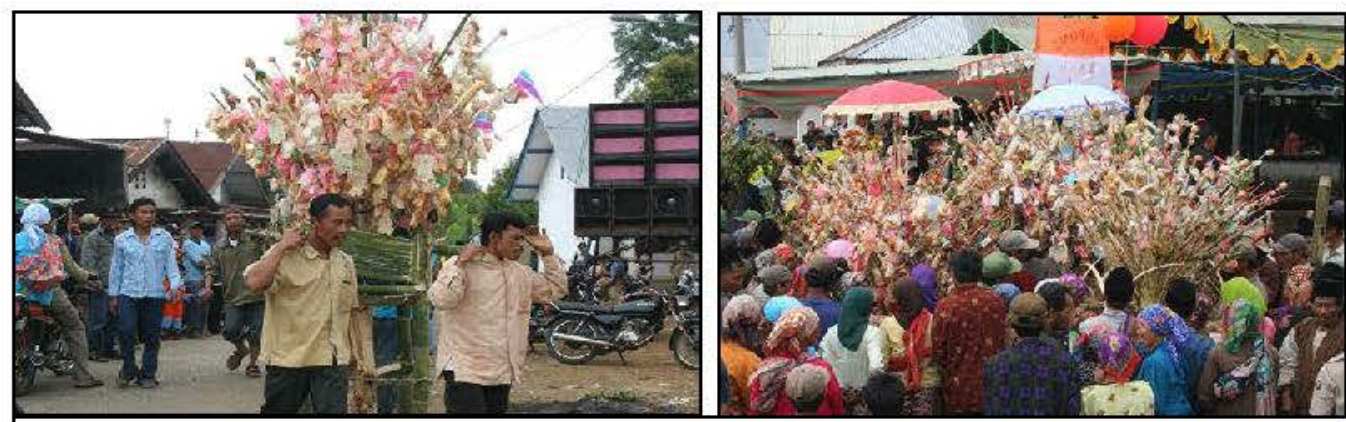

Foto 4: Ancak-ancak yang di buat oleh masyarakat lima dusun wilayah desa Pusungmalang
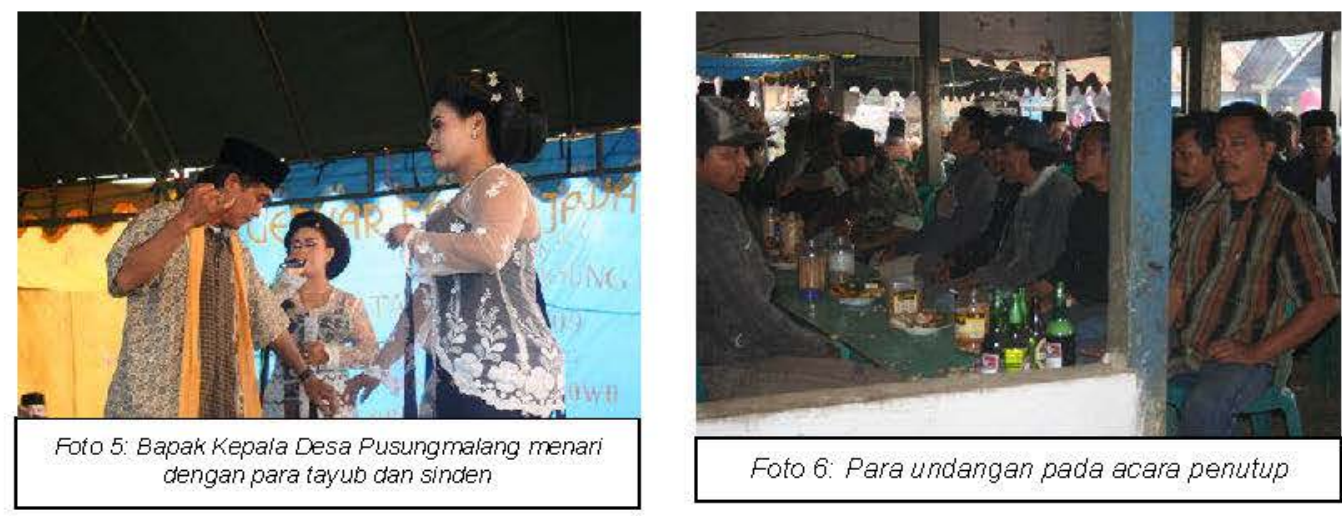

Foto 6: Para undangan pada acara penutup

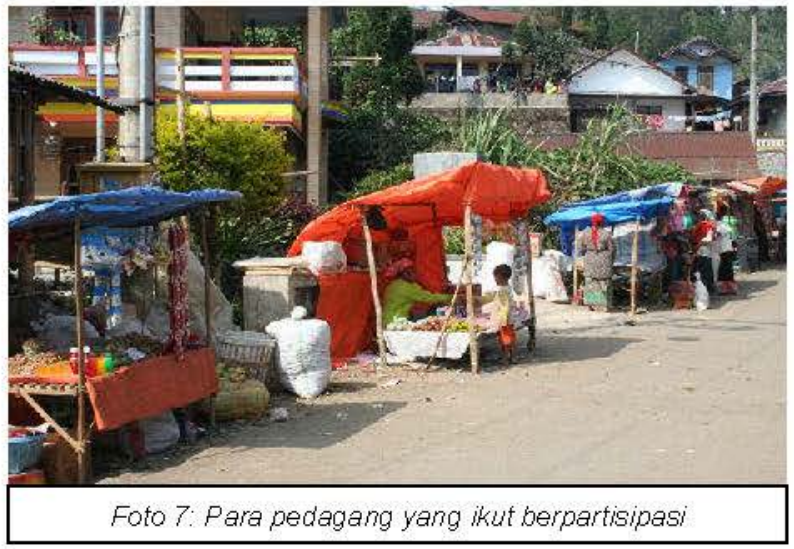




\section{KEPUSTAKAAN}

Garis-garis Besar Haluan Negara TAP MPR No.II/MPR/1988. Bahan Penataran P4 Pola Pendukung 100 jam Tahun 1991/1992. Jakarta: Departemen Pendidikan dan Kebudayaan.

Geertz, Clifford. 1989. Abangan, Santri, Priyayi Dalam Masyarakat Jawa. Oleh Aswab Mahasin (terj). Jakarta: Pustaka Jaya.

Istari, Rita TM. 2009. "Arsitektur Candi Sanggar di Lereng Gunung Bromo, Kabupaten Pasuruan (Tahap IV). Laporan Penelitian Arkeologi. Yogyakarta: Balai Arkeologi Yogyakarta.

Moertjipto, dkk. 1997/1998. Upacara Tradisional Mohon Hujan Desa Kepuhharjo, Cangkringan, Sleman, DIY. Yogyakarta: Direktorat Sejarah dan Nilai Tradisional, Depdikbud.

Sayogya, Subagyo. 1991. Ensiklopedi Nasional Indonesia jilid 16. Jakarta: PT Cipta Adi Pustaka.

Subalidinata, RS. 1982. Nilai-nilai Tradisional yang Tercermin Dalam Sastra Budaya Jawa (Fungsi dan Tugasnya). Makalah pada Sarasehan Nilai Kesejarahan dan Nilai Tradisional. Yogyakarta: Balai Kajian Sejarah dan Nilai Tradisional, Depdikbud.

Soetama, WE, dkk. 1988. Upacara Tradisional Jawa Tengah. Semarang: Proyek Inventarisasi dan Dokumentasi Kebudayaan Daerah Jawa Tengah.

Wales, Quaritch HG. 1948. "The Making of Greater India: A Study of South East Asia Culture Change". Dalam Journal of Royal Asiatic Society. London: Bemard Quaritch Ltd.

Koentjaraningrat. 1977. Beberapa Pokok Antropologi Sosial. Jakarta: PT Dian Rakyat.

Widodo, Sigit Sri. 1991. Kyai Ageng Gribig dan Upacara Tradisional Yaqowiyu di Jatinom Klaten Tahun 1986-1991 (Skripsi Sarjana). Yogyakarta: Jurusan Pendidikan Sejarah, Fakultas IImu Pengetahuan Sosial IKIP Sanata Dharma.

Pandit, Nyoman S. 1981. IImu Pariwisata. Jakarta: Pradnya Paramita.

Poerwadarminto, WJS. 1976. Kamus Umum Bahasa Indonesia. Jakarta: PN Balai Pustaka. 